\title{
Sustaining our future: resolving the conflict over population models
}

\author{
Peter Newman \\ Curtin University Sustainability Policy (CUSP) Institute \\ Email:P.Newman@curtin.edu.au
}

\begin{abstract}
If we are to sustain our future we have to resolve some fundamental issues about how to live on this planet. However underneath it all is a major issue: are there just too many of us? This paper will try to assess the question by looking at two conflicting models that stem from biology and from economics and try to suggest that the conflict can be resolved with new approaches to sustainable cities. It suggests that population issues on a global level need to be addressed as a matter of human rights but fear of population can be a dangerous diversion and prevent cities from grasping the opportunities (provided by growth) to achieve significant urban sustainability gains.
\end{abstract}

Keywords: population, urban sustainability, models, degrowth, IPAT. 


\section{INTRODUCTION}

The population debate is currently dominated by two distinct approaches that appear to be diametrically opposed. One comes from economics and involves increasing the population to stimulate the economy and to generate more skilled jobs, while the other comes from biology and advocates decreasing population in order to cope with environmental pressures such as climate change, peak oil and resource scarcities. The paper suggests that the two approaches for dealing with the future can be resolved by better understanding how urban sustainability is achieved.

It is argued that limiting population alone will not only do little in addressing the resource and environmental concerns facing cities and the nation, but it could produce entirely the opposite effect, that is, to ensure that the inefficiencies of the current system are locked in or stabilised in stagnant or declining cities. On the other hand, increasing population purely on economic grounds, and using current outdated and inefficient systems will undeniably result in higher carbon emissions and increasing environmental concerns.

The paper is suggesting a new approach for addressing the debate which uses the current and planned population growth in cities (generally accompanied by economic growth) to enable the implementation of new low carbon technologies and more intelligent infrastructure to transform cities into healthier, more liveable and productive low-carbon cities of the future. Thus if the urban sustainability model is better understood as a necessary and transformative approach then population growth can be used as a means to achieve it.

\section{A PERSONAL JOURNEY WITH POPULATION}

In 1970 I first heard Paul Ehrlich, the American population biologist speak about the environmental problems of the world and the link to population. His book The Population Bomb (Ehrlich, 1966) was a bestseller and began a long-term understanding amongst environmentalists that population was the underlying problem in global environmental issues. He was almost always opposed by economists who saw that population was a critical part of economic growth and this growth was essential for solving issues of improved economic welfare and distribution (Simon, 1980). The conflict has continued to this day and raises questions about whether the issue is unresolvable or whether there is a different system of thinking that can enable us to resolve population vs economic growth issues.

In his subsequent papers and texts Ehrlich developed his approach to population through what he called the IPAT model. The IPAT model (Impact $=$ Population $\mathrm{x}$ Affluence $\mathrm{x}$ Technology) suggests that every kind of technology has some kind of impact and that this will be amplified by consumption of whatever product the technology is producing and that this again will be multiplied by whatever quantum of population is doing the consumption. On the basis of this model population, consumption and technology all drive environmental impact and hence to reduce impact meant reducing all three. Debates about the importance of each factor resulted (eg Commoner, 1974) and there have been subsequent assessments of the quantitative value of the formula (eg Dietz, 1994; Chertow, 2001). The IPAT model remains as a dominant force in policy debates about the future, including as the basis of submissions to the recent population inquiry in Australia (DSEWPC, 2010). Popular assessments of the issue generally conclude that yes, we must reverse population or we can do little about our environmental problems.

After working with Ehrlich at Stanford in the early 1970s I became convinced that his IPAT model helped us understand the world and that economists just had to learn that they were wrong. However in the years that followed I began to suspect that something was not quite right with a simple IPAT model of solving environmental problems.

My first suspicions came when I began teaching a course on Population, Resources and Environment and found that all the evidence showed that there were two key drivers in reducing population. In rural areas the big driver is the freeing of women to receive education and to enable them to work, thus ensuring that their families had a future that was not just reliant on numbers of children (see most publications by United Nations Population Fund - UNFPA, eg Sadik, 2002). The other key driver was cities: people moving to cities immediately began having fewer children (UNEP, 1996). Both drivers propose that economic growth could enable a reduction of family sizes. However, in these situations, rather than population increase being facilitated by economic growth, the reverse was occurring. Population was declining.

Then I began to apply the IPAT formula to some of the big environmental issues in my own area. The biggest issues of the time were related to overgrazing in pastoral areas and the salinisation of agricultural soils in the Western Australian wheatbelt. Both places where these issues were rife in Western Australia had 
reducing populations, in fact they were already amongst the least populated in the world. They just had a wrong economic model for producing wealth. The model being used was not enabling them to consider the environment. The problem was not population, indeed if some of these rural areas did not have such population losses their local economies could have been more diverse and the need to have such local environmental impact would have reduced.

The biggest change in my understanding however came when I was elected to my local city council in Fremantle and found that every local issue we faced, including environmental issues about public transport, waste disposal and restoration of old buildings, was dominated by the fact that our population was rapidly declining. If IPAT was correct then environmental issues should be improving. I became a major proponent of the need for population growth and economic growth in the city in order to solve our environmental issues.

Eventually I could see that I was framing the issues of environmental policy wrongly, I had the wrong mental model. I needed to see that population, consumption and technology were not necessarily the problem. These parameters are each fundamental to economic growth and if we keep doing economic growth in a way that impacts on the environment, then these three factors are all going to cause environmental problems. However if economic growth can be shaped differently then these three factors can become tools for reducing environmental impact. This then became the philosophical difference between the two approaches to population: is economic growth being used to reduce impact or increase it?

Related to this has been a growing awareness that cities are not just crowded places where people are like ants or lemings but in fact the planet would be much more environmentally damaged if we were all living in the countryside (Hardoy et al., 2001). I also began collecting data on cities and found that the larger and denser the city the less impact they had on their environment (Newman and Kenworthy, 1999; Newman, 2006). A few economists have been documenting this also (Jacobs, 1969; 1984) especially in recent years where dense cities have been shown to be greener than low density suburbs (Sassen, 1994; Glaeser, 2010).

Was Ehrlich wrong in his IPAT model? Not really. He could see that the environment was suffering, that local and global limits were approaching and he could see that economic growth was fundamentally driving this process. Population, consumption and technology all conspired to cause this impact. Could a new economic growth model emerge that would enable him and others to see that a different approach was possible? To see it he would need to get beyond a simple biological model of people and the associated anticities approach so common to biologists. The major textbook where the Ehrlichs and John Holdren elaborated on their approach Population, Resources and Environment concluded the following about cities:

The deterioration of the environment, both physically and aesthetically, is most apparent in our cities. There seems to be abundant evidence that traditional cultural patterns break down in cities, and also that the high numbers of contacts with individuals not part of one's circle of regular social acquaintances may lead to mental disturbance. (Ehrlich et al., 1970: 177-178)

While working with this group at Stanford I wrote a paper with a different view about cities; it was about the structure and function of cities being modelled on ecosystems and here I found a much more positive potential for cities (Newman, 1975). It became the basis of subsequent work that enabled me to see that the IPAT model fails mostly because it simply does not understand cities. Before explaining this further let me complete the picture about the inadequacies of the IPAT model.

\section{THE PROBLEMS WITH ASSIGNING 'POPULATION AS THE PROBLEM'}

If population is the problem then a number of implications begin to follow. Population is people, it's not just numbers, and if people are a problem for the planet by merely being alive then obviously it would follow that we should do as much as possible to reduce the number of people. Thus policies that lead to reduced people are given priority, such as anti-immigration. The jingoistic nationalism that feeds on racism is given another basis for being allowed in public life. This can be given even greater support when allied with Social Darwinism, which also comes from biology, and has had a very poor history under totalitarian rulers. Pol Pot had a 'solution' to population when he imposed $12^{\text {th }}$ century Buddhism on his country and killed a third of its population to remove western influence. Hitler's solution to population was to remove the Jews and others he considered to be a blight on society. These extreme policies are not seen by the scientists emphasising population as part of their worldview but by dehumanising people as 'population' that needs to be 'reduced' the model is easily adapted into extremist views.

In reality the major population issues in third world villages are all to do with human rights not the need for more totalitarian control. The right for women to have access to education, to work and to birth control lie at 
the heart of why in some countries population continues to be an issue (UNFPA, 2005). Wherever these rights are respected then households have fewer children by choice (Surkyn and Lesthage, 2004).

There is an even more damaging aspect to emphasising the population 'solution' to environmental problems. There is an underlying despair about the inability to change society that is supported whenever population is seen as the major problem. Conservatism about the nature of our economy, about the nature of our cities and about the nature of political power, is supported when the fundamental issue is seen to be too many people. None of the other things are required to change, just reduce the numbers of people. The reform agenda, even for environmental reform, can be set back by this inherent conservatism and fear of population growth with its roots in population biology.

\section{SUSTAINABILITY AND THE GREEN ECONOMY}

On the other side of the story the economists who see growth at any costs as being the solution, need a good dose of population biology. If population growth is encouraged to enable more business as usual then impacts will accelerate. If population growth is seen as the basis for building more car-dependent suburbs, then IPAT will apply. There are physical limits and natural systems do matter. The denial of limits due to economic fundamentalism has had a long history and the need for Ehrlich and others to take them on has been an essential part of environmental reform. People and wildlife do get poisoned when unfettered release of chemicals happens as shown by Rachel Carson (1952). Land degradation and misuse of natural resources has led to the collapse of cities and civilisations for millennia (Diamond, 2005). Peak oil and climate change are real and require different cities and regions to be shaped through economic, social and political change (Newman et al., 2009).

Recognition that the old system of economic growth was broken was a major contribution from scientists like Paul Ehrlich. They did not need to divert the attention of policy makers to population reduction as the solution; they could have focused on the need for more fundamental change to the nature of economic growth. Rather than a kind of fundamentalism about economic purity (based on existing markets) the need to integrate understanding of economics and the environment began to be a common plea. Many scientists did take this direction and developed a major movement in global politics from the 1970s and 1980s asserting the need for a more ecological economics (eg the International Association for Ecological Economics and such influential books as Daly and Farley, 2004).

The need for economics to more deeply understand ecology is obvious and below I will try to show how this applies to cities. However, when this movement began to say that ecological limits meant third world development must be curtailed, that the planet was too overcrowded already, then alarm bells in the world governance systems began to ring. The third world was not impressed when told that a billion people, who went to bed hungry at night, had no chance to break out of their poverty. The biological model was running hard up against the economic development model and a resolution had to be found. The UN thus set up the World Commission on Environment and Development to find a resolution (WCED, 1987).

What emerged was the concept of sustainable development or sustainability, where economics and environmentalism had to begin to synergise rather than antagonise especially in ensuring long-term outcomes (WCED, 1987; Newman, 2006). That has since grown into what is now called the green economy or green growth by the OECD (2011a). Sustainability advocates soon recognised that the agenda was not just to reconcile biological issues and economic issues but that social issues had to be included in this mix. Thus the triple bottom line and the integration of economic, environmental and social outcomes became a major global agenda, reaching down into every level of government, every business and every community (Newman and Jennings, 2008; Newman, 2006). This resolution and integration is an on-going challenge and requires us to have different models of education and different models of thinking about our problems and solutions especially in our cities.

The contribution of the OECD in recent times to this on-going challenge is to try and emphasise the Green Economy and Green Growth as the way to see the future. They see the emerging economy of the Sixth Economic Wave as forging a new kind of economic world where sustainability technologies and processes are dominant as set out in Figure 1.

The central feature of this new green economy is that decoupling will occur of economic growth from fossil fuel growth, that the environmental footprint of our cities and regions will be reduced whilst increasing liveability (Hargroves and Smith, 2005). For those in the population biology model this would seem impossible as the nature of growth is to cause harm only; likewise for those in the economic fundamentalism model it will not be possible to reduce fossil fuel use without reducing economic growth as the two have 
been so tightly interconnected in the past. However if a different model of Green Growth can be forged then the resolution can be achieved.

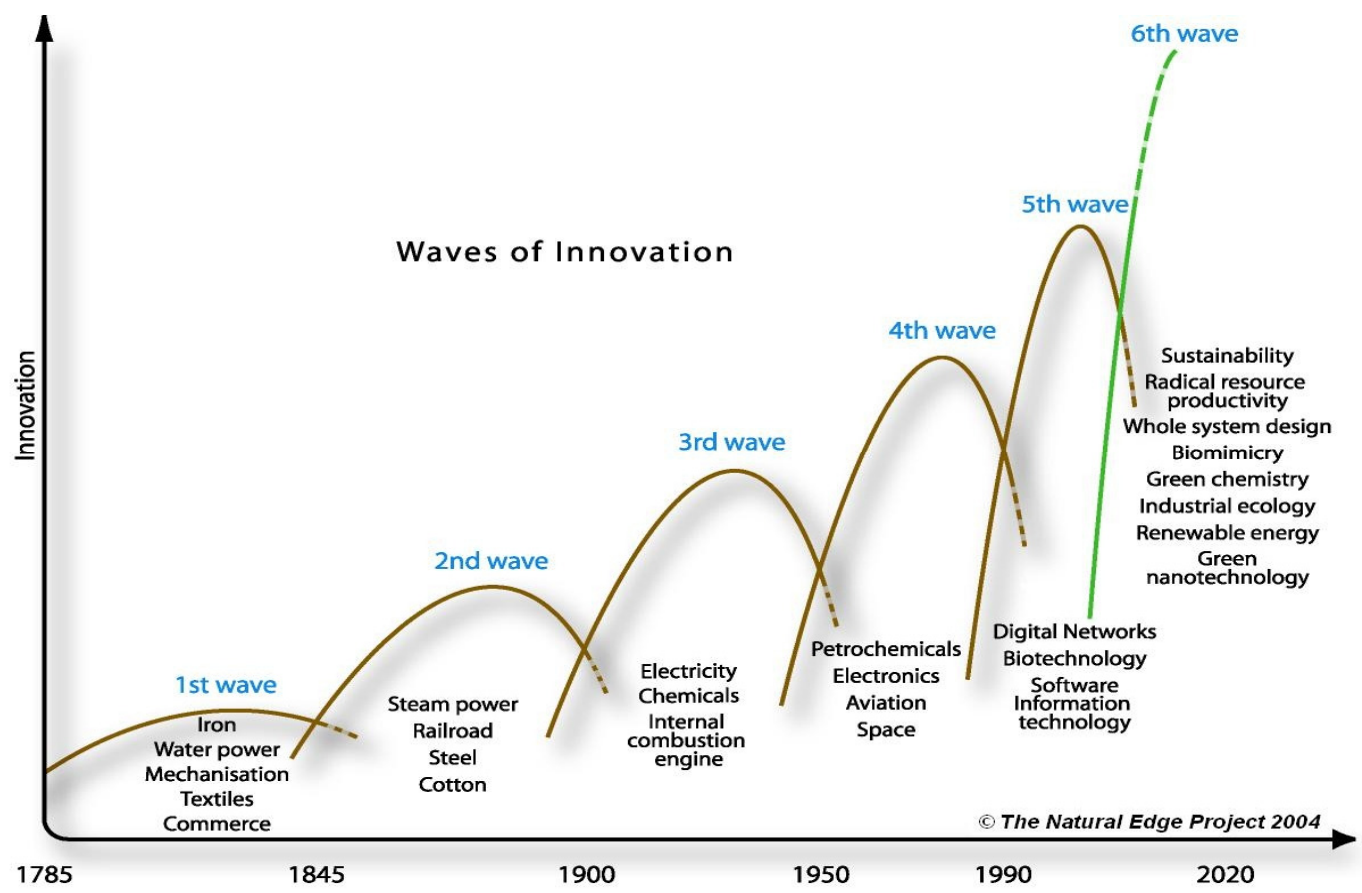

Figure 1. The waves of economic change and the rise of the sixth wave of the green economy Source: Hargroves and Smith (2005)

The kind of statements now appearing from OECD and from the UN include:

We need to make growth greener, to make our economic and environmental policies more compatible and even mutually-reinforcing. This is not just a matter of new technologies or new sources of renewable, safe energy. It is about how we all behave every day of our lives, what we eat, what we drink, what we recycle, re-use, repair, how we produce and how we consume. (Angel Gurria, OECD, 2011b)

The rewards of greening the world's economies are tangible and considerable, the means are at hand for both governments and the private sector, and the time to engage the challenge is now. (UNEP, 2011)

These sort of statements used to be associated with fringe green groups but are now coming from economists and ecologists in the world's mainstream organisations.

There are signs that the green economy is emerging as the following four 'peaks' appear to have happened:

- Peak car use appears to have started in the developed world cities in 2004 (Newman and Kenworthy, 2011);

- Peak oil use appears to have happened in 2006 (Deffeyes, 2005) as production has plateaued since then despite increasing demand and according to IEA (2010) it seems that at least conventional or cheap oil has peaked;

- Peak fossil fuel power investment in relation to investment in renewables appears to have occurred in 2009 (with around twice as much investment in renewables as fossil fuel-based power plants in 2010) (REN21, 2011);

- Peak fossil fuel power consumption in developed countries appears to have happened in 2009/10 with many places like California doing this many years before places like Australia (Australian Energy Regulator, 2010; US Department of Energy, 2011).

All of these trends will accelerate when global agreements on decarbonising the world economy are made more certain. Meanwhile those nations and cities that are prepared to begin the transition with commitment are going to be the ones who benefit the most from the new opportunities. 


\section{THE OPPORTUNITIES PROVIDED BY GREEN GROWTH}

Each of the trends outlined above associated with declining fossil fuel use is also associated with growth in something else, growth in renewables, growth in fuel efficient cities due to greater redevelopment, growth in public transport, cycling and walking, growth in biofuels... All of this growth is economic growth, it will be reflected in growth in GNP. Economic growth is about opportunity; it used to be about opportunities in the fossil fuel industry and its many flow-ons throughout society in the fourth wave, but that is over. Now, in the sixth wave, it is about new energy sources, new efficiencies, new technologies, new processes that can help resolve the needs of the green economy (OECD, 2011a).

The biological model that cannot see the possibility of a transformed economy continues to have some appeal. Tim Jackson in his book Prosperity without Growth: Economics for a Finite Planet (Jackson, 2009) has become the central exponent of what is called the 'degrowth' movement. Growth is seen as the fundamental problem just as in the IPAT model. E.F. Schumacher in his classic book Small is Beautiful: Economics as if People Mattered (Schumacher, 1974) says that we should never lose the value of the words 'growth' and 'progress', they just need to be reclaimed and given a meaning that does not include destruction of the earth. Apart from the soiling of an important word the 'degrowth' movement is missing the opportunities that are created by the green growth of the sixth wave. The problem is not growth, it is the type of growth.

Underneath the new understanding of economic growth is an understanding of the significance of cities and the need for a new model of urban sustainability. The 'degrowth' movement, like the IPAT movement before them, does not seem to understand the possibilities of a new kind of green urbanism and the chance to use the next stage of economic growth to facilitate this.

\section{THE EMERGING URBAN SUSTAINABILITY MODEL}

There is an emerging new model for how ecological footprint can be dramatically reduced which can be labelled the Urban Sustainability model. It consists of new urban infrastructure, new urban form and new urban management. Together it provides us with an opportunity to resolve the issue about population and economic growth as this new model for how we build, shape and manage cities is in fact the basis of the new green economy. It can enable us therefore to welcome economic growth rather than fearing it as the transformation to a green economy becomes the main agenda.

\section{Urban Infrastructure}

The kind of infrastructure required will enable significant reductions in fossil fuels, water, other materials and waste (thus reducing the footprint) whilst enabling cost-effective urban areas that are better places to live. The technologies to achieve this are set out in Rauland and Newman (2011). The kind of solutions to producing this set of outcomes can now be modelled in the design process using such sophisticated models as CCapCity produced by Kinesis, building on work done by Landcom in NSW (Beattie et al., 2011). In a recent study of the Cockburn Coast for LandCorp in Perth we used the model to determine the best footprint reductions for the least cost. The results are set out in Figure 2 below. The list of infrastructure provided is set out on the side of the figure and the result was a cost of just $\$ 5600$ per dwelling. The rapid growth and deployment of these technologies in the future will continue to reduce this cost.

The need to adopt the new urban infrastructure of decentralised energy, water and waste systems is rapidly becoming mainstream policy (Rauland and Newman, 2011). The massive gains in decarbonising a city in a short period of time are appealing to urban policy makers across the globe. However, there are several factors that must be addressed as part of the change.

\section{Urban Form}

Urban form cannot be separated from these new urban technologies. Just as reducing car use needs to involve a polycentric city with dense centres of activity, the new green infrastructure outlined above can only work with dense centres as their fundamental focus (Beattie and Newman, 2011). Higher density is also easier to achieve in a city experiencing growth, as the increasing demand for new housing can be channelled through this. Thus the focus of new economic development in cities needs to be on a range of new centres across the city that are linked by quality public transport, have walkable urban design at their heart, and feature all the decentralised green infrastructure along with green buildings.

There is growing evidence that the biggest market for housing is now in these kind of centres where people have access to the amenity and services of a city and the option of quality, sustainable transport modes with all their health and productivity benefits (Kelly, 2011). 


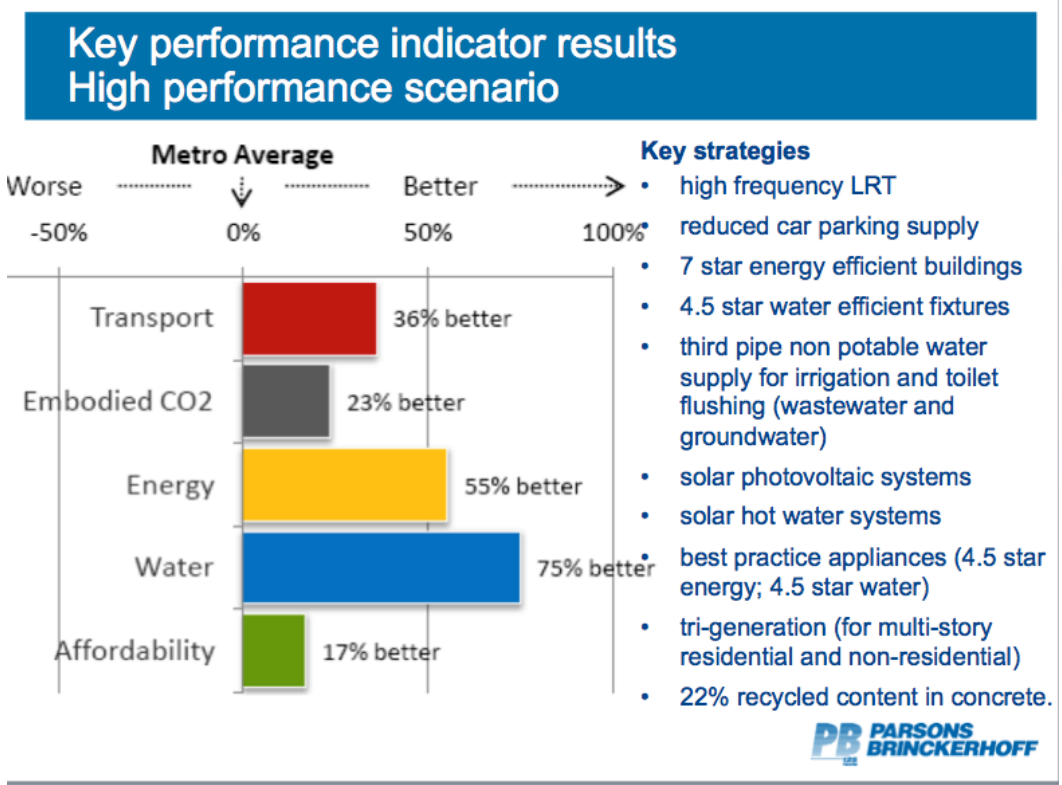

Figure 2. Results of a modelling exercise on how to reduce urban footprint for the least cost. The resultant cost was $\$ 5600$ per dwelling.

\section{Urban Management}

These new combinations of technology and urban form will need new urban management systems. These distributed energy, water and waste systems will require localised urban utilities or district utility groups. They will fit into the broader grids of the present city but can best be facilitated by local municipalities establishing public-private partnerships with communities, as has happened in Woking, Vauban and other centres of green innovation (Newman et al., 2009; Bunning, 2011).

These changes to cities - new urban infrastructure, new urban form and new urban management - can be called the Urban Sustainability model. This model offers any city in the developed or developing world a new approach to the future - one that can accommodate a growing population with significantly reduced footprint.

\section{THE ECONOMIC AND HEALTH OUTCOMES OF URBAN SUSTAINABILITY}

The new model will require a lot more detailed study to outline the full benefits and costs of building in such ways including the benefits from reduced car use for such things as health and productivity. However, a notional set of data that characterise the new kind of urban areas has been put together below based on a series of our studies, especially Trubka et al. (2010). They are summarised in Table 1.

One of the key outcomes of the new Urban Sustainability model is the notion that they are healthier cities than our previous high fossil fuel-based city and the first data supporting that are in Table 1. Not only will there be less air pollution from the fossil fuel burning but there will be a lot less car use with a series of benefits in terms of reduced obesity and increased health and productivity in the work place that are highly significant.

\section{HOW DOES THE URBAN SUSTAINABILITY MODEL LINK TO POPULATION GROWTH?}

There is increasing need to transform the cities of the world along the lines of the Urban Sustainability model. Cities need to adopt these decentralised urban systems and rebuild themselves to become low carbon through new infrastructure, urban form and urban management. It will require new investment from public and private sources, new capital that can replace the sunk capital already invested in old model cities with largescale energy, water and waste systems as well as freeways and urban sprawl. Such capital may come from a city that has no population or economic growth but it is often extremely hard politically and institutionally to take away or redirect current investment. One of the great advantages of growing populations and growing urban economies is that fresh investments and new demonstrations are usually much easier to achieve. Thus, new investment in transformative change can be made more easily in cities that are growing. 
Table 1. Notional cost comparisons for the new urban sustainability model compared to a Business As Usual car dependent city building model. Costs are per new dwelling.

\begin{tabular}{|c|c|c|c|}
\hline \multicolumn{4}{|c|}{$\begin{array}{l}\text { Transport and Land use Characteristics } \\
\text { NOTE: Typical characteristics for an Australian City. }\end{array}$} \\
\hline Car trips per person per day & 2.32 & 3.39 & \\
\hline Transit trips per person per day & 0.56 & 0.165 & \\
\hline Transit accessibility & $\begin{array}{r}\text { more than } 80 \% \mathrm{w}>15 \mathrm{~min} \\
\text { service }\end{array}$ & less than $15 \% \mathrm{w}>15 \mathrm{~min}$ service & \\
\hline Walk/Cycle trips per person per day & 2.115 & 0.945 & \\
\hline Distance to CBD & less than $10 \mathrm{~km}$ & more than $40 \mathrm{~km}$ & \\
\hline GhG per capita daily (CO2 -e) & 0 to $4 \mathrm{Kg}$ & 8 up to $10 \mathrm{Kg}$ & \\
\hline Activity density (pop and jobs per ha) & $>35$ & $<20$ & \\
\hline \multicolumn{4}{|l|}{ Infrastructure Costs } \\
\hline Roads & $\$ 5,086.56$ & $\$ 30,378.88$ & $\$ 25,292.32$ \\
\hline Water and Sewerage & $\$ 14,747.62$ & $\$ 22,377.46$ & $\$ 7,629.84$ \\
\hline Telecommunications & $\$ 2,576.11$ & $\$ 3,711.85$ & $\$ 1,135.74$ \\
\hline Electricity & $\$ 4,082.12$ & $\$ 9,696.51$ & $\$ 5,614.39$ \\
\hline Gas & & $\$ 3,690.84$ & $\$ 3,690.84$ \\
\hline Fire and Ambulance & & $\$ 302.51$ & $\$ 302.51$ \\
\hline Police & & $\$ 388.42$ & $\$ 388.42$ \\
\hline Education & $\$ 3,895.46$ & $\$ 33,147.27$ & $\$ 29,251.81$ \\
\hline Health (Hospitals, etc.) & $\$ 20,114.87$ & $\$ 32,347.33$ & $\$ 12,232.46$ \\
\hline Total Infrastructure & $\$ 50,502.74$ & $\$ 136,041.07$ & $\$ 85,538.33$ \\
\hline \multicolumn{4}{|l|}{ Transport Costs } \\
\hline Transport and Travel Time & $\$ 206,542.06$ & $\$ 342,598.10$ & $\$ 136,056.04$ \\
\hline Roads and Parking & $\$ 46,937.54$ & $\$ 154,826.10$ & $\$ 107,888.56$ \\
\hline Externalities & $\$ 2,219.88$ & $\$ 9,705.38$ & $\$ 7,485.50$ \\
\hline Total Transport & $\$ 255,699.48$ & $\$ 507,129.58$ & $\$ 251,430.10$ \\
\hline \multicolumn{4}{|l|}{ Greenhouse Gas Cost } \\
\hline Offset Cost $(\$ 25 / \mathrm{t})$ & $\$ 2,500.00$ & $\$ 5,400.00$ & $\$ 2,900.00$ \\
\hline Social Cost $(\$ 215 / \mathrm{t})$ & $\$ 21,500.00$ & $\$ 46,440.00$ & $\$ 24,940.00$ \\
\hline (NB. not included in total) & & & \\
\hline Total Greenhouse & $\$ 2,500.00$ & $\$ 5,400.00$ & $\$ 2,900.00$ \\
\hline \multicolumn{4}{|l|}{ Physical Activity Costs } \\
\hline Healthcare Costs of inactivity* & & $\$ 4,229.95$ & $\$ 4,229.95$ \\
\hline Productivity Loss & & $\$ 34,454.90$ & $\$ 34,454.90$ \\
\hline Total Activity Costs & & $\$ 38,684.85$ & $\$ 38,684.85$ \\
\hline Total (excluding social cost) & $\$ 308,702$ & $\$ 687,255$ & $\$ 378,553$ \\
\hline
\end{tabular}

*Includes Social costs. This can be divided into direct and indirect costs. This includes the health impacts of obesity and air pollution.

This growth must become green growth and employ models like the Urban Sustainability model. Those cities that are given the opportunity of growing in the next few decades must take these chances to forge the new green economy. Rather than seizing degrowth and decreasing their populations they need to demonstrate a new kind of growth that can leave a legacy of low carbon living. The degrowth movement will just lock 
cities into the urban infrastructure, urban forms and urban management of the previous growth eras based on cheap fossil fuels.

\section{THE FUNDAMENTALS BEHIND POPULATION: TWO MODELS OF UNDERSTANDING THE WORLD}

The conflict over population comes down to an understanding of what is meant by economic growth and this is determined by either an understanding derived from biology or from economics; what I have tried to do in this paper is show that they can be integrated using the Urban Sustainability model.

The IPAT model developed by Ehrlich et al. (1970) is derived from biology and suggests that the only true policy for a city would be for it to reduce its population and to reduce its affluence as these will always overwhelm any gains in technology. Population, consumption and technology are all seen as negative as all feed economic growth and this is universally seen as negative for the planet. It is essentially anti-people and anti-economic growth. This approach has been picked up by the degrowth movement in recent years.

An anti-people, degrowth model is not a policy setting that can ever appeal to an urban politician - especially one in the developing world where people continue to flock to cities seeking the benefits of economic growth through new opportunities for the future. It is also not a policy that can achieve the required transformative changes in cities outlined in this paper. Cities adopting the IPAT model for policy can only age into oblivion. It is a policy that does not understand cities. It is a policy of despair.

On the other hand we also cannot continue to use an economic model that does not recognise the new limits of the earth. The changes in thinking are happening amongst economists such as Moller (2010) who talks about the "age of scarcity" that economists now work within. They must begin to see that green growth is the only option for the future and hence begin to recognise the need for the Urban Sustainability model for cities.

The Urban Sustainability model accepts that urban footprint must be reduced but in a way that enables greater opportunities for people. Thus population, affluence and technology can all be positive contributions to economic growth in cities. Economic growth is about opportunity and change. The opportunity and changes for any city in this period of history are to create cities with low or zero carbon impacts - this is the challenge of the green economy as set out by the OECD. It suggests that economic growth need not be negative if it is able to take on the new agendas described above of new urban infrastructure, new urban forms and new urban management. This is a positive policy that can be adopted by politicians who want to embrace this opportunity for change. It is a policy of hope.

For politicians and policy-makers willing to take on an urban policy that is positive about population and economic growth in their cities, there is one key proviso that must be made. If the acceptance or even welcoming of population and economic growth is done as business-as-usual, then the IPAT model will come into play and there will be no decrease in carbon outputs which will indicate a failure to address this fundamental challenge. Accepting the growth of population and the economy in the "age of scarcity" where low carbon outcomes are an essential indicator of successful urban policy, must involve new low carbon approaches to urban infrastructure, urban form and urban management. These policy arenas must be stimulated by, and done in parallel with, the growth of the city. Only then will the transformative change happen that can demonstrate the positive value in growing populations in cities.

\section{CONCLUSIONS AND POLICY IMPLICATIONS}

Understanding population growth issues is not simply a matter of trying to either be pro or anti the economic growth associated with this. It's a matter of seeing that there is a qualitatively different approach to growth in cities that is both necessary and possible. If cities are not understood as dynamic systems requiring a new approach to their sustainability based on decentralised infrastructure and sustainable transport, then they can only be seen as negative places with little reason to support and thus they probably could be allowed to die. This leaves little hope and is a major cause for the despair underlying many places around the globe. The Urban Sustainability model on the other hand is essentially a hopeful approach to the future and can generate major social and political change.

While any city can essentially begin the transition, there are several reasons why cities experiencing population growth may find it easier, and therefore be more likely to achieve the transformation required than those without growth. These include: the greater impetus and motivation to upgrade existing (often inefficient) infrastructure and systems as additional people place increasing pressure on outdated systems; the need to accommodate additional people in new and modern ways (ie through increasing density); and greater 
financial capacity to enable implementation of the new low carbon technologies, innovations and urban change required.

Several cities have begun to demonstrate how these low carbon technologies and approaches can help to make the transformative changes required to decarbonise their cities. The next global agenda will be dominated by a competition to see how cities can achieve faster and faster reductions in footprint whilst creating different kinds of cultural and social liveability through the many opportunities created in the green economy. Cities stuck in a model based on the problems of population growth (and degrowth) as well as those cities stuck in a model based on the need to keep old style economic growth, will slowly decline and die.

Cities have a journey to go on as they approach the issues of sustainability. So do we personally. The story above tells some of my story, especially about the cul-de-sac of population. Cities need more people to go on the journey and move from a fear of population to accepting the opportunity of population growth as a means to grasp a more sustainable future.

\section{ACKNOWLEDGMENT}

The author acknowledges the financial support of the Australian Research Council.

\section{REFERENCES}

Australian Energy Regulator (2010). State of the Energy Market 2010. www.aer.gov.au.

Beattie, C., and Newman, P. (2011). The density trade-off: Does high rise construction contribute more than single dwellings to greenhouse gas emissions? State of Australian Cities Conference, Perth.

Beattie, C., Bunning, J., Stewart, J., and Anda, M. (2011). Carbon assessment models for urban development. Greenhouse Gas Measurement and Management (in press).

Bunning, J. (2011). Governance models supportive of distributed green infrastructure for decarbonised resilient cities. State of Australian Cities Conference, Perth.

Carson, R. (1952). Silent Spring. Houghton Mifflin, New York.

Chertow, M.R. (2001). The IPAT equation and its variants: Changing views of technology and environmental impact. Journal of Industrial Ecology. 4(4), 13-29.

Commoner, B. (1972), The environment cost of economic growth, pp. 339-363. In R. G. Ridker (Ed.) Population, Resources and the Environment. U.S. Government Printing Office, Washington DC.

Daly, H., and Farley, J. (2004). Ecological Economics: Principles and Applications. Island Press, Washington DC.

Deffeyes, K.S. (2005). Beyond Oil: The View from Hubbert's Peak. Hill and Wang, New York.

Department of Sustainability, Environment, Water, Population and Communities (DSEWPC) (2010). A Sustainable Population Strategy for Australia. DSEWPC, Australian Government, Canberra.

Dietz, T. (1994). Rethinking the environmental impacts of population, affluence and technology. Human Ecology Review. 1, 277-300.

Diamond, J. (2005). Collapse: How Societies Choose to Fail or Succeed. Viking Books, New York.

Ehrlich, P.R. (1968). The Population Bomb. Ballantine, New York.

Ehrlich, P.R., Ehrlich, A.H., and Holdren, J.P. (1970). Population, Resources and Environment. Freeman, San Francisco CA.

Glaeser, E. (2010). The Triumph of the City: How Our Greatest Invention Makes Us Richer, Smarter, Greener, Healthier and Happier. Macmillan, London.

Hardoy, J., Mitlin D., and Satterthwaite, D. (2001). Environmental Problems in an Urbanizing World. Earthscan, London.

Hargroves, K., and Smith, M.H. (Eds) (2005). The Natural Advantage of Nations. Earthscan Books, London. International Energy Agency (IEA) (2010). World Energy Outlook. IEA, Paris.

Jackson, T. (2005). Prosperity without Growth: Economics for a Finite Planet. Earthscan, London.

Jacobs, J. (1969). The Economy of Cities. Random House, New York.

Jacobs, J. (1984). Cities and the Wealth of Nations. Penguin, Harmondsworth.

Kelly, J.F. (2011). The Housing We'd Choose. Grattan Institute, Melbourne.

Moller, J.E. (2010). How Asia Can Shape the World: From the Era of Plenty to the Era of Scarcities. Institute of South East Asian Studies, Singapore.

Newman, P. (1975). An ecological model for city structure and development. Ekistics. 40, 258-265.

Newman, P., and Kenworthy, J. (1999). Sustainability and Cities: Overcoming Automobile Dependence. Island Press, Washington DC. 
Newman, P., and Kenworthy, J. (2011). Peak car use: urban planning needs to change. http://www.thefifthestate.com.au/archives/24214.

Newman, P., Beatley, T., and Boyer, H. (2009). Resilient Cities: Responding to Peak Oil and Climate Change. Island Press, Washington DC.

Newman, P. (2006). The environmental impact of cities. Environment and Urbanization. 18(2), 275-295.

Newman, P., and Jennings, I. (2008). Cities as Sustainable Ecosystems: Principles and Practice. Island Press, Washington DC.

OECD (2011a). Towards Green Growth. OECD, Paris.

OECD (2011b). Better Policies for Better Lives, OECD Secretary-General Angel Gurría. OECD Week, OECD, Paris.

Rauland, V., and Newman, P. (2011). Decarbonising Australian cities: A new model for creating low carbon, resilient cities, MODSIM Conference, Perth.

REN21 (2011). Renewables 2011: Global Status Report, REN21 Secretariat, Paris.

Sadik, N. (Ed.) (2002). An Agenda for People: The UNFPA through Three Decades. New York University Press, New York and London.

Sassen, S. (1994). Cities and the World Economy. Pineforge Press, Thousand Oaks CA.

Schumacher, E.F. (1974). Small is Beautiful: Economics as if People Mattered. Abacus, London.

Simon, J. (1980). Resources, population, environment: An oversupply of false bad news. Science. 208, 14311437.

Surkyn, J., and Lesthaege, R. (2004). Value orientations and the second demographic transition in Northern, Western and Southern Europe: An update. Demographic Research. 3(3), 45-99.

Trubka, R., Bilsborough, D., and Newman, P. (2010). The costs of sprawl. Environment Design Guide. GEN $83,84,85$.

UNEP (1996). An Urbanizing World: Global Report on Human Settlements 1996. UNEP/Habitat, Oxford, University Press, Oxford.

UNEP (2011). Towards a Green Economy: Pathways to Sustainable Development and Poverty Eradication. United Nations Environment Program, Nairobi.

UNFPA (2005). State of the World Population 2005. United Nations, New York.

US Department of Energy (2011). Energy Efficiency and Renewable Energy. www.energy. Gov/states//electricity

World Commission on Environment and Development (WCED) (1987). Our Common Future. Oxford University Press, Oxford. 


\section{Appendix: Basis of cost estimates in Table 1}

Functions and sources used in establishing the costs.

\begin{tabular}{|c|c|}
\hline \multicolumn{2}{|l|}{ Transport and Land use Characteristics } \\
\hline VKT per person & \\
\hline Car trips per person per day & Based on Melbourne. Source: Kenworthy and Newman 2000. \\
\hline Transit trips per person per day & $\begin{array}{l}\text { Based on Melbourne. Source: Kenworthy and Newman } 2000 \text {. } \\
\text { US Active Living Research Program (2009) } 29 \% \text { of people who use public transport } \\
\text { were physically active for } 30+\text { minutes per day, due primarily to walking to and from } \\
\text { transit stops and transit users compared to car users walked } 30 \% \text { more steps per day } \\
\text { and spent } 8.3 \text { more minutes walking per day. }\end{array}$ \\
\hline Transit accessibility & $\begin{array}{l}\text { Transit accessibility relates to the proportion of land within an urbanised area that is } \\
\text { within } 400 \mathrm{~m} \text { of a full-service bus or tram, or within } 800 \mathrm{~m} \text { of a train station. 'Full- } \\
\text { service' is defined as a route operating seven days a week with at least four services } \\
\text { per hour on weekdays and Saturdays during the day and two services per hour on } \\
\text { Sundays and holidays. }\end{array}$ \\
\hline Walk/Cycle trips per person per day & Based on Melbourne. Source: Kenworthy and Newman 2000. \\
\hline Density & Walkable areas had +30 mins exercise per week. \\
\hline \multicolumn{2}{|l|}{ Distance to CBD } \\
\hline GHG per capita daily (CO2 -e) & $\mathrm{Y}=[0.073$ (Distance to CBD) -0.25 (Transit accessibility) +4.35$]$ \\
\hline Activity density & $\begin{array}{l}\text { Jobs plus residences. } \\
\text { Frank et al. }(2004) \text { conclude that each quartile increase in mixed land use results in a } \\
12.2 \% \text { reduction in the likelihood of obesity across different genders and ethnicities. } \\
\text { Permeable }=250 \text { intersections within one square mile }\end{array}$ \\
\hline \multicolumn{2}{|l|}{ Infrastructure Costs } \\
\hline $\begin{array}{l}\text { Roads } \\
\text { Water and Sewerage }\end{array}$ & $\begin{array}{l}\text { ABS (2008) and WAPC (2001)- weighted inflation rate from the Consumer, Producer } \\
\text { and Labour Price Indices. WAPC (2001) comparative costs. }\end{array}$ \\
\hline Telecommunications & \\
\hline Electricity & \\
\hline Gas & \\
\hline Fire and Ambulance & \\
\hline Police & \\
\hline Education & \\
\hline Health (Hospitals, etc.) & \\
\hline
\end{tabular}

\begin{tabular}{ll}
\hline Transport Costs & \\
\hline Transport and Travel Time & $\begin{array}{l}\text { Newman and Kenworthy, 1999- weighted inflation rate from the Consumer, Producer } \\
\text { and Labour Price Indices, where possible. } \\
\text { Roads and Parking }\end{array}$ \\
Externalities &
\end{tabular}

\begin{tabular}{ll}
\hline Greenhouse Gas Cost & \\
\hline Offset Cost $(\$ 25 / \mathrm{t})$ & $\begin{array}{l}2007 . \mathrm{GHG}=(365 \text { days/yr)(price/kg CO2-e) (No. of dwellings)(Inhabitants/dwelling) } \\
(0.073 \mathrm{x}-0.25 \mathrm{z}+4.35)\end{array}$ \\
Social Cost $(\$ 215 / \mathrm{t})$ & UK Government Economic Service $\$ 175$ in $2000,=\$ 217$ in 2007
\end{tabular}

Physical Activity Costs

Healthcare Costs of inactivity

Direct

Indirect
$\$ 1.5$ billion (Ecotech, 2007) = cost of inactivity. $54.2 \%$ of Australia's over 18 population is inactive. Therefore $\$ 2.8$ billion is the cost associated with an inactive population.

Health Canada's Economic Burden of Illness (1993) appropriates $54.3 \%$ of the total cost of illness to indirect health $=$ Estimate Australia's indirect cost of inactivity at $\$ 1.78$ billion, the total cost of inactivity at $\$ 3.28$ billion. 
Newman, Sustaining our future: resolving the conflict over population models

Productivity Loss
2.1 day reduction in workdays lost due to illness, stress, or waning workplace satisfaction (absenteeism) and 6.2\% increased ability for employees to focus on tasks and maintain focus for longer periods of time (presenteeism or on-the-job productivity) based on averages from Shephard (1992) and Lechner and de Vries (1997). Using Australian weekly earnings average of \$AU1165.40 as the baseline level of productivity, and an average development of 1000 dwelling with an average of 1.83 adults of over 18 . 